\title{
熱可塑性樹脂の射出成形における適応制御
}

\author{
一型内樹脂温度変化の解析一
}

\author{
焼本数利 $* 1 * 2 \cdot$ 前川善一郎 $* 1 \cdot$ 濱田泰以 ${ }^{* 1} \cdot$ 酒井忠基*2
}

\section{Adaptive Process Control in Injection Molding}

\author{
-Prediction of the Temperature Variation \\ of Polymer in the Cavity-
Kazutoshi YaKemoto*1*2 Zenichiro MaEKaWA ${ }^{* 1}$. Hiroyuki HAMADA ${ }^{* 1}$. Tadamoto SAKAI $* 2$

\begin{abstract}
Product quality and consistency in the injection molding process are largely dominated by the temperature variations of the mold wall or of the polymer inside the barrel. As a critical step for the development of process control to solve the fluctuations in product quality caused by temperature variations, a new method to predict the temperature variation of polymer in the cavity was investigated.

An equation to predict the temperature variation of polymer in the cavity was derived by using heat conduction analysis. This equation is believed to be adequate in accuracy, reliability, and applicability to process control. In this derivation, the conduction heat transfer during the filling and holding pressure stage, and the viscous dissipation during the filling stage were investigated.

The validity of the equation was investigated experimentally by using GPPS, PP, and POM under the conditions of varying mold temperature and of varying polymer temperature inside the barrel. And the measured and calculated temperature variations of polymer in the cavity were compared.

As a result, the temperature variation of polymer in the cavity, which may practically happen during the injection molding process, could be estimated with accuracy by the equation presented in this study. And the equation could be applied to predict product weight fluctuations in advance of the filling stage. So, it was confirmed that the prediction method presented in this study can be applied effectively to the adaptive process control.
\end{abstract}

Key words : Injection molding/Polymer temperature/Mold wall temperature/Conduction heat transfer/Process control

*1 京都工芸繊維大学

京都市左京区松ケ崎御所海道町（广 606）

Kyoto Institute of Technology

Matsugasaki Goshokaido-cho, Sakyo-ku, Kyoto 606 Japan

*2 (株) 日本製鋼所 機械・電子技術研究所

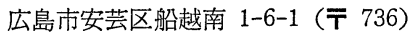

The Japan Steel Works Ltd.

1-6-1 Funakoshi-Minami, Aki-ku, Hiroshima 736

Japan

1992.3. 19 受理

\section{1. 緒言}

溶融粘度や収縮率を始めとするプラスチック材料諸 物性の特徵の一つに, その温度依存性が大きいことが あげられる. また, 射出成形品の生産は, 金型や樹脂 の温度が大小変動する下で行われるのが一般的である. このため, 温度変化は成形品品質の変動を引き起こす 主原因の一つとなっている，第 1 報1) で示したように， 溶融粘度の温度依存性が大きい材料では, 型内の樹脂 
Fig. 1 Schematic diagram of the procedures to predict polymer temperature variation in the cavity

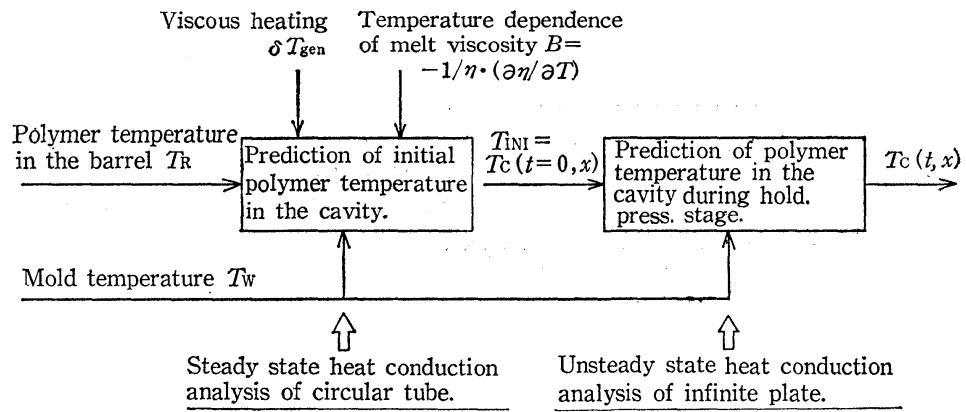

圧力や成形品重量にも変動が現れやすい，㶢こで，品 質の再現性を維持するために種々のプロセス制御手法 が提案されてきた. しかし, 従来の型内圧力制御のよ らに, 温度変化を考慮しない制御では, 得られる品質 とその再現性に限界があることを第 2 報2)て報告した。 したがって, 精密射出成形に沶いては温度変化を考慮 したプロセス制御技術が必要である。

金型に射出された溶融樹脂の温度と流動性は, 冷却 作用を受けて急速に低下寸る. そして, 流動性が消失 してキャビティへの樹脂供給がなくなると，最終的な 成形品重量や収縮率が決定される。このため, 所定精 度の成形品を得るためには，この流動性が低下した時 点での型内圧力や密度を制御する必要がある. しかし， 流動性が低下した時点で樹脂の挙動を制御することは 困難となる，このため，形状精度などの成形品品質を 制御するためには，型内の樹脂が高い流動性を有して 制御が可能な充填初期の段階に括いて, 密度および応 力など型内の樹脂の状態変化を予測する制御方式が有 望である. 型内の樹脂の状態変化を予測するためには， 型内の樹脂温度も予測によって得る必要がある.

型内の樹脂温度を予測して制御を行う場合, 予測値 の精度と信頼性が不充分であれば, 制御によって, か えって品質の变動を促す可能性がある. このため, 温 度の予測值を制御に用いる際には, その精度之信頼性 を考慮した温度の捉え方が必要とされる。

型内の樹脂温度の絶対値を正確に予測するためには, 比熱, 熱伝導率などの樹脂物性値の他, あらゆる計算 条件に正確さが必要である. しかし, 高圧, 急冷下に ある型内の樹脂物性值と, 低圧, 熱的平衡条件下で測 定された物性值との間には差異が起り得る。このため, 制御に用いる予測值としては, 極力, 樹脂物性值への 直接的な依存度が小さいものが望をれる。たと光ば， 成形ショット間の变化量のみに限定すれば, 絶対値を 問題とする場合に比べて，樹脂物性値への直接的な依 存度は減少することが予測される。

従来, 温度变化を考慮したプロセス制御が種々提案
されている3゙ 6). しかし，型内の樹脂温度の予測につ いては, 熱伝導率を無限大とみなした熱伝導解析解の 級数第一項の及を考慮した近似式や3),4)，保圧冷却段 階で支配的となる伝導伝熱を考虑していないもの か報告されていない，また，予測值の精度の検証，お。 よび樹脂物性值への依存度の検討は不充分であった。

本報では, 熱伝導解析手法を用いて, 成形ショット 間に和壮る型内の樹脂温度の变化量を予測する方法を 検討した。 そして, その予測精度を実験で検証し, 適 応制御への適用性を検討した。

\section{2. 型内の樹脂温度変化の予測式}

\section{1 解析手順}

本報の解析手順を Fig. 1 に示す. 保圧冷却段階に おけりる金型キャビティ内の樹脂温度変化を，充媜完了 時の樹脂温度を初期值とする非定常熱伝導として解析 する. また, 充填完了時の樹脂温度を求めるため, 溶 融樹脂が加熱シリンダーからキャビティに流入するま での温度降下を定常熱伝導として解析する。ただし， 粘性発熱は，そのほとんどが充填段階において発生す ると考兄られるので, 後者の場合にのみ考慮した.

\section{2 保圧冷却段階における型内の樹脂温度変化}

キャビティ部の樹脂を Fig. 2 亿示すように，金型 壁面に囲まれた無限平板と夕なし，その伝導伝熱を対 象とする. 樹脂の比熱, 熱伝導率, および密度の温度

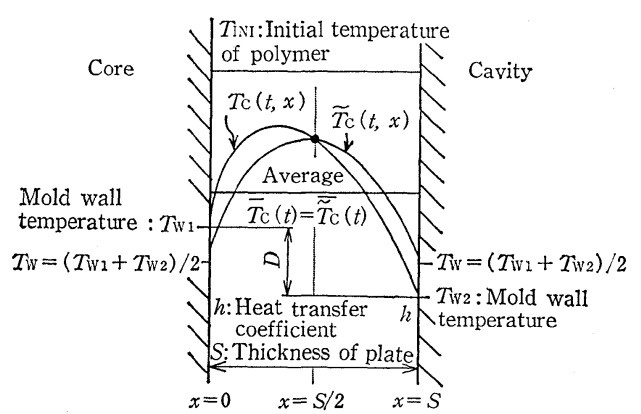

Fig. 2 Schematic diagram of infinite plate heat conduction model 


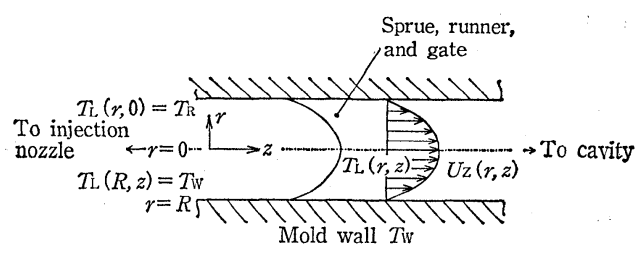

Fig. 3 Schematic diagram of circular tube heat conduction model

依存性と相変化は考慮せず, 壁面温度は常に一定と仮 定する.また，充填完了時の温度は一栐とする。この モデルは次の熱伝導方程式で表される7).

$$
\rho \cdot c_{p} \cdot\left(\frac{\partial T_{\mathrm{C}}}{\partial t}\right)_{x}=\lambda \cdot\left(\frac{\partial^{2} T_{\mathrm{C}}}{\partial x^{2}}\right)_{t}
$$

初期条件 : $T_{\mathrm{C}}(t=0, x)=T_{\mathrm{INI}}$

境界条件 $: \lambda \cdot\left(\frac{\partial T_{\mathrm{C}}}{\partial x}\right)_{x=0}=h \cdot\left(T_{\mathrm{C}}-T_{\mathrm{W} 1}\right)$,

$$
\lambda \cdot\left(\frac{\partial T_{\mathrm{C}}}{\partial x}\right)_{x=S}=h \cdot\left(T_{\mathrm{W} 2}-T_{\mathrm{C}}\right)
$$

$\rho:$ 樹脂密度 $\left(\mathrm{kg} / \mathrm{m}^{2}\right), c_{p}$ : 定圧比熱 $\left(\mathrm{J} / \mathrm{kg} \cdot{ }^{\circ} \mathrm{C}\right), \lambda$ : 熱伝導率 $\left(\mathrm{W} / \mathrm{m} \cdot{ }^{\circ} \mathrm{C}\right), S:$ 肉厚 $(\mathrm{m}), t$ : 時刻 $(\mathrm{s})$, $x$ : 断面位置 $(0 \sim S)(\mathrm{m}), h$ : 金型と樹脂との間の熱 輻射, 接触熱抵抗を含む総括的な熱伝達率 $\left(\mathrm{W} / \mathrm{m}^{2} \cdot{ }^{\circ} \mathrm{C}\right)$, $T_{\mathrm{C}}(t, x)$ : 時刻 $t$, 位置 $x$ の型内樹脂温度 $\left({ }^{\circ} \mathrm{C}\right), T_{\mathrm{INI}}$ : 型内の 樹脂温度初期值 (充填完了時) $\left({ }^{\circ} \mathrm{C}\right), T_{\mathrm{W} 1}$ : 可動側壁面温度 $\left({ }^{\circ} \mathrm{C}\right), T_{\mathrm{w} 2}$ : 固定側 壁面温度 $\left({ }^{\circ} \mathrm{C}\right)$

可動側拉よび固定側壁面温度 $T_{\mathrm{W} 1}, T_{\mathrm{W} 2}$ と, 樹脂温 度初期值 $T_{\mathrm{INI}}$ がそれぞれ， $T_{\mathrm{W} 1}{ }^{\prime}, T_{\mathrm{W}{ }^{2}}{ }^{\prime}, T_{\mathrm{INI}}{ }^{\prime}$ に变化 し, 型内の樹脂温度 $T_{\mathrm{C}}$ が $T_{\mathrm{C}}{ }^{\prime}$ に変化したとする. この時, 固定された時刻 $t$ と位置 $x$ での型内の樹脂温

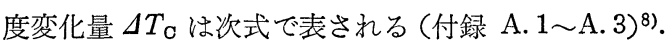

$$
\begin{aligned}
\Delta T_{\mathrm{C}}= & \left(\frac{\partial T_{\mathrm{C}}}{\partial T_{\mathrm{W}}}\right)_{D, T_{\mathrm{INI}}} \cdot \Delta T_{\mathrm{W}}+\left(\frac{\partial T_{\mathrm{C}}}{\partial D}\right)_{T_{\mathrm{W}}, T_{\mathrm{INI}}} \cdot \Delta D \\
& +\left(\frac{\partial T_{\mathrm{C}}}{\partial T_{\mathrm{INI}}}\right)_{T_{\mathrm{W}}, D} \cdot \Delta T_{\mathrm{INI}} \\
= & \frac{T_{\mathrm{INI}}-T_{\mathrm{C}}+E \cdot D}{T_{\mathrm{INI}}-T_{\mathrm{W}}} \cdot \Delta T_{\mathrm{W}}+E \cdot \Delta D \\
& +\frac{T_{\mathrm{C}}-E \cdot D-T_{\mathrm{W}}}{T_{\mathrm{INI}}-T_{\mathrm{W}}} \cdot \Delta T_{\mathrm{INI}} .
\end{aligned}
$$

ただし，

$$
\begin{aligned}
& \Delta T_{\mathrm{O}}=T_{\mathrm{O}^{\prime}}(t, x)-T_{\mathrm{C}}(t, x), \Delta T_{\mathrm{w}}=T_{\mathrm{w}}{ }^{\prime}-T_{\mathrm{w}}, \\
& \Delta D=D^{\prime}-D, \Delta T_{\mathrm{INI}}=T_{\mathrm{INI}}{ }^{\prime}-T_{\mathrm{INI}} \text {, } \\
& T_{\mathrm{w}}=\left(T_{\mathrm{w} 1}+T_{\mathrm{w} 2}\right) / 2, \quad D=T_{\mathrm{w} 1}-T_{\mathrm{w} 2}, \\
& T_{\mathrm{w}}{ }^{\prime}=\left(T_{\mathrm{W} 1}{ }^{\prime}+T_{\mathrm{w} 2}{ }^{\prime}\right) / 2, \quad D^{\prime}=T_{\mathrm{w} 1}{ }^{\prime}-T_{\mathrm{w} 2}{ }^{\prime}, \\
& E=(h \cdot S / \lambda) \cdot(1 / 2-x / S) /[2+(h \cdot S / \lambda)]
\end{aligned}
$$

(2) 式によれば, $\Delta T_{\mathrm{C}}$ が直接依存する樹脂物性值 は熱伝導率 $\lambda$ と熱伝達率 $h$ であり, 比熱 $c_{p}$ と密度 $\rho$ に直接依存しない，直接依存しないとは，これらが未 知でも， $\Delta T_{\mathrm{C}}$ を計算できるといらことである.
特別な場合として断面中心部 $(x=S / 2)$ の $T_{\mathrm{C}}$ と, 断面方向平均温度 $\bar{T}_{\mathrm{C}}(t)$ については次式が成立する.

$$
\begin{aligned}
\Delta T_{\mathrm{C}} & =\left(\frac{\partial T_{\mathrm{C}}}{\partial T_{\mathrm{W}}}\right)_{T_{\mathrm{INI}}} \cdot \Delta T_{\mathrm{W}}+\left(\frac{\partial T_{\mathrm{C}}}{\partial T_{\mathrm{INI}}}\right)_{T_{\mathrm{W}}} \cdot \Delta T_{\mathrm{INI}} \\
& =\frac{T_{\mathrm{INI}}-T_{\mathrm{C}}}{T_{\mathrm{INI}}-T_{\mathrm{W}}} \cdot \Delta T_{\mathrm{W}}+\frac{T_{\mathrm{C}}-T_{\mathrm{W}}}{T_{\mathrm{INI}}-T_{\mathrm{W}}} \cdot \Delta T_{\mathrm{INI}}
\end{aligned}
$$

ただし，断面方向平均温度 $\bar{T}_{\mathrm{C}}$ は次式で定義される.

$$
\bar{T}_{\mathrm{C}}(t)=\frac{1}{S} \cdot \int_{0}^{S} T_{\mathrm{C}}(t, x) \mathrm{d} x
$$

この場合, $\Delta T_{\mathrm{C}}$ は樹脂物性值 $\lambda$ と $h$ 飞も直接依存 しない. $T_{\mathrm{W} 1}$ と $T_{\mathrm{W} 2}$ とを平均化し, $T_{\mathrm{w} 1}=T_{\mathrm{w} 2}=T_{\mathrm{W}}$ と仮定した時の (1) 式の解を $\widetilde{T}_{\mathrm{C}}$ と打くと, $T_{\mathrm{W} 1} \neq$ $T_{\mathrm{W} 2}$ となる一般的な場合の $T_{\mathrm{C}}$ と次式の関係にある.

$$
T_{\mathrm{C}}=E \cdot\left(T_{\mathrm{W} 1}-T_{\mathrm{w} 2}\right)+\widetilde{T}_{\mathrm{C}}
$$

(3) 式と (5) 式から, 断面中心部 $(x=S / 2)$ の $T_{\mathrm{C}}$ 抢よび断面平均温度 $\bar{T}_{\mathrm{C}}(t)$ については Fig. 1 に 示したように, $T_{\mathrm{C}}$ と $\widetilde{T}_{\mathrm{C}}$ とは常に一致する. このた め, 断面中心部特よび断面方向に平均した樹脂温度变 化は, 壁面温度を平均化すれば (4) 式で求められる.

\section{3 充填完了時の型内の樹脂温度変化}

スプルー, ランナー, 拈よびゲート部を含む樹脂流 路を, Fig. 3 亿示す円管として近似する. 加熱シリン ダー内の樹脂がキャビティ部に到達する過程において， 型壁面への伝導伝熱, 対流熱移動, お上び流動化伴う 粘性発熱を考慮する.また，管内の流れは層流と仮定 する.このモデルは次式で表される92 11).

$$
\rho \cdot c_{p} \cdot U_{z} \cdot\left(\frac{\partial T_{L}}{\partial z}\right)_{r}=\lambda \cdot \frac{1}{r} \cdot \frac{\partial}{\partial r}\left(r\left(\frac{\partial T_{L}}{\partial r}\right)_{z}\right)_{z}+\eta \cdot \dot{\gamma}^{2}
$$

境界条件: $T_{L}(r, 0)=T_{R}, T_{L}(R, z)=T_{\mathrm{w}}, U_{z}(r):$ 軸 方向流速 $(\mathrm{m} / \mathrm{s}), T_{L}(r, z)$ : 位置 $r, z$ の樹脂温度, $r$ : 径方向座標 $(0 \sim R)(\mathrm{m}), z$ : 軸方向座標, $R$ : 管 径 $(\mathrm{m}), T_{R}$ : 射出される樹脂温度 (加熱シリンダー 内樹脂温度 $), \eta\left(\dot{\gamma}, T_{R}\right):$ 温度 $T_{R}$, ずり速度 $\dot{\gamma}$ にお ける溶融粘度 $(\mathrm{Pa} \cdot \mathrm{s}), \dot{\gamma}:$ ずり速度 $\left(\partial U_{z} / \partial r\right)\left(\mathrm{s}^{-1}\right)$

溶融粘度はべき乗法則に従い, その温度依存性は, 射出される樹脂温度 $T_{R}$ のみによるものと仮定する.

$$
\eta\left(\dot{\gamma}, T_{\mathrm{R}}\right)=m \cdot \dot{\gamma}^{n-1} \cdot \exp \left[-B \cdot\left(T_{\mathrm{R}}+273\right)\right]
$$

ただし， $B=-(1 / \eta) \cdot(\partial \eta / \partial T) \dot{\gamma}\left({ }^{\circ} \mathrm{K}^{-1}\right), m, n:$ 材料 定数.

充填段階は, 射出速度が一定とみなせるので, 金型 への樹脂流量 $Q\left(\mathrm{~m}^{3} / \mathrm{s}\right)$ が一定と仮定する. そして, 流動末端の 固定された位置 $r_{s}, z_{s}$ における樹脂温度 を充填完了時のキャビティ部の樹脂温度と仮定する.

$$
T_{\mathrm{INI}}=T_{L}\left(r_{s}, z_{s}\right)
$$

$T_{L}$ は, 対流および伝導伝熱項によって決定される温 
度 $T_{L 0}$ と, 粘性発熱による温度上昇 $\delta T_{\text {gen }}$ との和で 表される（付録 A.4）.

$$
T_{L}=T_{L 0}+\delta T_{\text {gen }}
$$

金型温度 $T_{\mathrm{W}}$ と射出される樹脂温度 $T_{\mathrm{R}}$ がそれぞれ， $T_{\mathrm{w}^{\prime}}, T_{\mathrm{R}}{ }^{\prime}$ 飞変化した場合, 充填完了時の 型内の樹脂 温度変化量 $\Delta T_{I N I}$ は, 次式で求められる(付録 A.5).

$$
\begin{aligned}
\Delta T_{\mathrm{INI}} \doteq & \left(\frac{\partial T_{\mathrm{INI}}}{\partial T_{\mathrm{W}}}\right)_{T_{\mathrm{R}}} \cdot \Delta T_{\mathrm{W}}+\left(\frac{\partial T_{\mathrm{INI}}}{\partial T_{\mathrm{R}}}\right)_{T_{\mathrm{W}}} \cdot \Delta T_{\mathrm{R}} \\
= & \left(\frac{T_{\mathrm{R}}-T_{\mathrm{INI}}}{T_{\mathrm{R}}-T_{\mathrm{W}}}+\frac{\delta T_{\mathrm{gen}}}{T_{\mathrm{R}}-T_{\mathrm{W}}}\right) \cdot \Delta T_{\mathrm{W}} \\
& +\left[\frac{T_{\mathrm{INI}}-T_{\mathrm{W}}}{T_{\mathrm{R}}-T_{\mathrm{W}}}-\left(\frac{1}{T_{\mathrm{R}}-T_{\mathrm{W}}}+B\right) \cdot \delta T_{\mathrm{gen}}\right] \\
& \times \Delta T_{\mathrm{R}}
\end{aligned}
$$

(10)式に执いて等号が厳密に成り立たないのは，(7) 式で示した $T_{\mathrm{R}}$ とクとの関係が線形とならないため である.一方， $T_{\mathrm{w}}$ と $T_{\mathrm{INI}}$ とは線形関係にある.

\section{4 適用方法}

（10）式を（4）式に代入すると次式を得る.

$$
\begin{aligned}
\Delta T_{\mathrm{C}} & =\left(\frac{\partial T_{\mathrm{C}}}{\partial T_{\mathrm{W}}}\right)_{T_{\mathrm{R}}} \cdot \Delta T_{\mathrm{W}}+\left(\frac{\partial T_{\mathrm{C}}}{\partial T_{\mathrm{R}}}\right)_{T_{\mathrm{W}}} \cdot \Delta T_{\mathrm{R}} \\
= & \left(\frac{T_{\mathrm{R}}-T_{\mathrm{C}}}{T_{\mathrm{R}}-T_{\mathrm{W}}}+\frac{T_{\mathrm{C}}-T_{\mathrm{W}}}{T_{\mathrm{INI}}-T_{\mathrm{W}}} \cdot \frac{\delta T_{\mathrm{gen}}}{T_{\mathrm{R}}-T_{\mathrm{W}}}\right) \cdot \Delta T_{\mathrm{W}} \\
& +\left[\frac{T_{\mathrm{C}}-T_{\mathrm{W}}}{T_{\mathrm{R}}-T_{\mathrm{W}}}-\frac{T_{\mathrm{C}}-T_{\mathrm{W}}}{T_{\mathrm{INI}}-T_{\mathrm{W}}} \cdot\left(\frac{1}{T_{\mathrm{R}}-T_{\mathrm{W}}}+B\right)\right. \\
& \left.\times \delta T_{\text {gen }}\right] \cdot \Delta T_{\mathrm{R}}
\end{aligned}
$$

上式によれば，基準となる温度 $T_{\mathrm{R}}, T_{\mathrm{W}}, T_{\mathrm{INI}}, T_{\mathrm{C}}$ と, 粘度の温度依存性 $B$, 特よび粘性発熱による温度 上昇 $\delta T_{\mathrm{gen}}$ を与兄れば, 金型温度の变化量 $\Delta T_{\mathrm{W}}$ と 射出される樹脂温度の変化量 $\Delta T_{\mathrm{R}}$ とから, 型内の樹 脂温度变化量 $\Delta T_{\mathrm{C}}$ を計算できる. 特に, 粘性発熱仡 よる温度上昇量 $\delta T_{\text {gen }}$ が 0 の場合, (11) 式は次式と なる。

$$
\Delta T_{\mathrm{C}}=\frac{T_{\mathrm{R}}-T_{\mathrm{C}}}{T_{\mathrm{R}}-T_{\mathrm{W}}} \cdot \Delta T_{\mathrm{W}}+\frac{T_{\mathrm{C}}-T_{\mathrm{W}}}{T_{\mathrm{R}}-T_{\mathrm{W}}} \cdot \Delta T_{\mathrm{R}}
$$

すなわち粘性発熱が無い場合， $\Delta T_{\mathrm{C}}$ は $B, \delta T_{\mathrm{gen}}$ ，お よび $T_{\mathrm{INI}}$ にも直接依存しなくなる.

型内の樹脂が流動停止温度 $T_{\mathrm{nf}}\left({ }^{\circ} \mathrm{C}\right)^{12)}$ を迎兄る時 刻 $t_{\mathrm{nf}}$ は, 成形品の重量や収縮率の決定に大きな要因 となる， $t_{\mathrm{nf}}$ を求めるためには，(1) 式と（6）式の 解を計算する必要があり, $t_{\mathrm{nf}}$ には樹脂物性值の $c_{p}$,

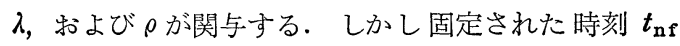
の樹脂温度变化を問題とすれば, 粘度の温度依存性 $B$ と粘性発熱量 $\delta T_{\text {gen }}$ 以外は関与しない。

金型と射出学れる樹脂の温度が $T_{\mathrm{W}} *, T_{\mathrm{R}}{ }^{*}$ の基準 となる成形ショットに扮いて, 時刻 $t_{\mathrm{nf}}$ の型内の樹脂 の断面平均温度 $\bar{T}_{\mathrm{C}}{ }^{*}(t)$ が $T_{\mathrm{nf}}$ であるとする. 別の 成形ショットで $T_{\mathrm{W}}{ }^{*}, T_{\mathrm{R}}{ }^{*}$ がそれぞれ $T_{\mathrm{W}^{\prime}}{ }^{\prime}, T_{\mathrm{R}}{ }^{\prime}$ に変

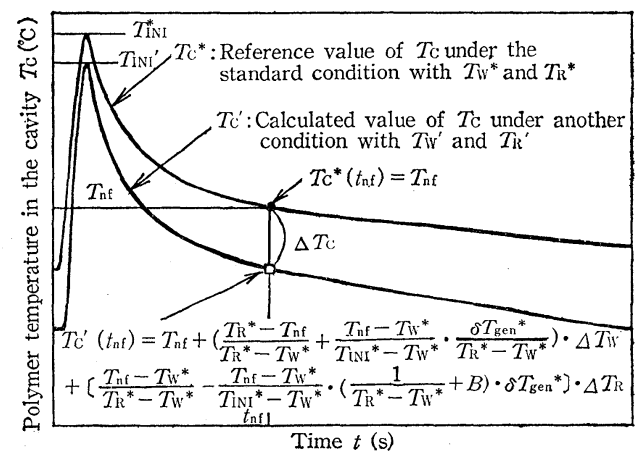

Fig. 4 Schematic diagram of the calculation of polymer temperature variation in the cavity

化した場合, 型内の樹脂温度 $\bar{T}_{\mathrm{C}^{\prime}}\left(t_{\mathrm{nf}}\right)$ は次式となる。

$$
\begin{aligned}
& \bar{T}_{\mathrm{c}}{ }^{\prime}\left(t_{\mathrm{nf}}\right)=T_{\mathrm{nf}}+\Delta \bar{T}_{\mathrm{c}}\left(t_{\mathrm{nf}}\right) \\
& =T_{\mathrm{nf}}+\left(\frac{T_{\mathrm{R}}{ }^{*}-T_{\mathrm{nf}}}{T_{\mathrm{R}}{ }^{*}-T_{\mathrm{W}}{ }^{*}}+\frac{T_{\mathrm{nf}}-T_{\mathrm{w}}{ }^{*}}{T_{\mathrm{INI}}{ }^{*}-T_{\mathrm{w}} *} \cdot \frac{\delta T_{\mathrm{gen}}{ }^{*}}{T_{\mathrm{R}}{ }^{*}-T_{\mathrm{w}} *}\right) \\
& \times \Delta T_{\mathrm{W}}+\left[\frac{T_{\mathrm{nf}}-T_{\mathrm{W}} *}{T_{\mathrm{R}} *-T_{\mathrm{W}} *}-\frac{T_{\mathrm{nf}}-T_{\mathrm{W}} *}{T_{\mathrm{INI}} *-T_{\mathrm{W}} *}\right. \\
& \left.\times\left(\frac{1}{T_{\mathrm{R}}{ }^{*}-T_{\mathrm{w}}{ }^{*}}+B\right) \cdot \delta T_{\mathrm{gen}} *\right] \cdot \Delta T_{\mathrm{R}}
\end{aligned}
$$

ただし $, \Delta T_{\mathrm{W}}=T_{\mathrm{W}}{ }^{\prime}-T_{\mathrm{w}}{ }^{*}, \Delta T_{\mathrm{R}}=T_{\mathrm{R}}{ }^{\prime}-T_{\mathrm{R}}{ }^{*}$

$\bar{T}_{\mathrm{C}}{ }^{\prime}\left(t_{\mathrm{nf}}\right)$ と $T_{\mathrm{nf}}$ との関係を Fig. 4 に示す.

$\bar{T}_{\mathrm{C}}{ }^{\prime}\left(t_{\mathrm{nf}}\right)$ を求める上では $t_{\mathrm{nf}}$ を必要としない，こ のため，プロセス制御に用いる情報としては， $t_{\mathrm{nf}}$ を 直接求めるよりも, 固定された時刻 $t_{\mathrm{nf}}$ の樹脂温度変 化を問題とする汇らが，予測值の樹脂物性值への直接 的な依存度が小さく，信頼度は高くなると考光られる。

\section{3. 実験方法および装置}

\section{1 供試材料之成形品}

供試材料には，一般用ポリスチレン (GPPS, デンカ スチロール MW-1, 電気化学工業製), ポリプロピレ ン (PP, 住友ノーブレン AY 564, 住友化学工業製), 抒よびポリアセタール（POM，ジュラコン M 90-02, ポリプラスチックス製)を用いた.

各材料のみかけの溶融粘度 $\eta(\mathrm{Pa} \cdot \mathrm{s})$ を温度 5 水準, せん断速度 10 水準て測定し, 測定データを(7) 式 で近似した. 測定装置には, 東洋精器製作所製キャピ ログラフ $1 \mathrm{~B}$ 型（キャピラリ $\phi 0.001 \times 0.04 \mathrm{~L}(\mathrm{~m}))$ を用いた。

成形品は，参考文献2) で示した箱型の 1 個取り（肉 厚 $0.003(\mathrm{~m})$, 投影面 $0.065 \times 0.070(\mathrm{~m})$, 制限ゲー ト $0.0015 W \times 0.0015 H \times 0.002 L(\mathrm{~m}))$ とした.

\section{2 射出成形装置}

射出成形機には，日本製鋼所製 J $100 \mathrm{EP}$ (型締力 


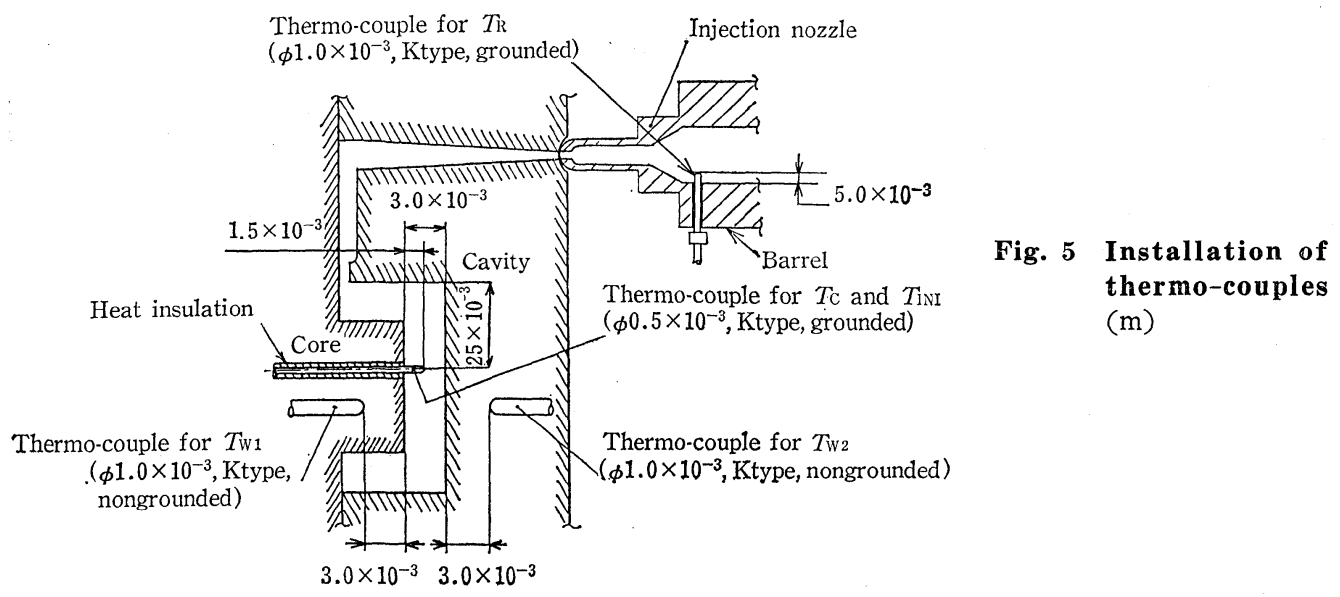

$0.98 \times 10^{6}(\mathrm{~N})$ ，スクリ二径 $\phi 0.040(\mathrm{~m})$ ，サーボ弁 による圧力速度の閉ループ制御)を使用した.

金型温度調節器には，松井製作所製 MC III-135/31 $\mathrm{HX}$ を使用し，金型温度設定値 $T_{\mathrm{ws}}\left({ }^{\circ} \mathrm{C}\right)$ は，冷媒 （水）の設定温度とし，固定側，可動側ともに同一と した.

\section{3 計測装置と方法}

温度は全て熱電対で計測した．Fig. 5 に，熱電対の 取付図を示す，型内の樹脂温度 $T_{C}$ は，可動側金型に 熱電対 $\left(\phi 0.5 \times 10^{-3}(\mathrm{~m}), \mathrm{K}\right.$ 型接地式)を取り付け, これをキャビティ断面に突き出して計測した．突き出 乙量は, 断面中心部の樹脂温度を計測するため, 成形 品厚さの半分となる $1.5 \times 10^{-3}(\mathrm{~m})$ とした.

樹脂の熱伝導率は，金型壁面を形成する鋼の熱伝導 率にくらべて相当小さいため, 金型壁面と熱電対とが 直接接触すると，熱電対の計測值が金型壁面温度に影 響され，樹脂の温度を正しく検出しない可能性がある。 そこで, Fig. 5 に示したセラミックス製の断熱チュー ブ (内径 $\phi 0.5 \times 10^{-3}(\mathrm{~m})$, 外径 $\phi 1.5 \times 10^{-3}(\mathrm{~m})$ ) を熱電対の外周に装着して $T_{\mathrm{C}}$ を計測した。

固定側金型温度 $T_{\mathrm{W} 1}$ と可動側金型温度 $T_{\mathrm{W} 2}$ を計 測するため，キャビティ表面から $3.0 \times 10^{-3}(\mathrm{~m})$ の 深さの位置にそれぞれ熱電対 $\left(\phi 1.0 \times 10^{-3}(\mathrm{~m}), \mathrm{K}\right.$ 型 非接地式）を取り付けた。

射出される樹脂温度 $T_{\mathrm{R}}$ は，加熱シリンダ一内壁 部から中心部に向けて熱電対 $\left(\phi 1.0 \times 10^{-3}(\mathrm{~m}), \mathrm{K}\right.$ 型接地式)を $0.005(\mathrm{~m})$ 突き出して計測した。

$T_{\mathrm{C}}$ は，充填開始から計測し，樹脂がキャビティに 充填されて $T_{\mathrm{C}}$ が最大值を示す時刻を $0(\mathrm{~s})$ とし, この時刻の $T_{\mathrm{C}}$ を型内の樹脂温度初期值 $T_{\mathrm{INI}}$ とし た.また， $T_{\mathrm{W} 1}, T_{\mathrm{W} 2}$ 预よび $T_{\mathrm{R}}$ は射出開始時に計測 し, $T_{\mathrm{W}}=\left(T_{\mathrm{W} 1}+T_{\mathrm{W} 2}\right) / 2$ により平均金型温度 $T_{\mathrm{W}}$ を 求めた。

\section{4 成形条件}

実際の生産中に起こり得る温度変化を設定し，この 条件下で (11) 式の予測精度を検証する。このため, 成形条件として，加熱シリンダ一設定温度 $T_{\mathrm{RS}}$ 括よ び金型温度設定值 $T_{\mathrm{WS}}$ を大きく変化させた場合と， 成形立ち上がり時とを設定し，各条件下で，それぞれ 25 ショットの成形を連続して行った. $T_{\mathrm{RS}}$ および $T_{\mathrm{WS}}$ を大きく変化させる場合には，あらかじめ 金型温度 $T_{\mathrm{W}}$ 抢よび射出される樹脂温度 $T_{\mathrm{R}}$ がショット間で医 とんど変化しなくなるまで成形を行った後， $T_{\mathrm{ws}}$ と $T_{\mathrm{RS}}$ を $20^{\circ} \mathrm{C}$ 増加させて成形を続行してデータを採取 した．成形立ち上がり時には，金型に何ら樹脂を射出 せず， $T_{\mathrm{W}}$ および $T_{\mathrm{R}}$ がそれぞれ $T_{\mathrm{WS}}$ および $T_{\mathrm{RS}}$ に近い一定值を示した状態から成形を開始してデータ を採取した，そして，計算に使用するための基準とな る金型温度 $T_{\mathrm{W}}{ }^{*}$, 射出される樹脂温度 $T_{\mathrm{R}}{ }^{*}$, 抢よび 型内の樹脂温度の計測値 $T_{\mathrm{C}}$ *を採取するため， $T_{\mathrm{WS}}$ および $T_{\mathrm{RS}}$ を一定とし， $T_{\mathrm{W}}$ 和よび $T_{\mathrm{R}}$ が安定した ところでデータを採取した。

次に, $T_{\mathrm{W}}, T_{\mathrm{R}}$ 拈よび保圧 $p_{\mathrm{L}}$ を 3 水準に変化させ て成形品を採取し，(13）式を用いた樹脂温度計算值 と，型内圧力および成形品重量との関連を検討した。

\section{5 計算方法}

計算值と実測値との比較は，キャビティ断面中心部 の樹脂温度を対象として行った，基準となる成形ショ ットの金型温度 $T_{\mathrm{W}}$ ，射出される樹脂温度 $T_{\mathrm{R}}{ }^{*}$ ，拈

\section{Table 1 Parameters of the power} law model

\begin{tabular}{c|c|c|c}
\hline Material & $m \times 10^{-7}\left(\mathrm{~Pa} \cdot \mathrm{s}^{n}\right)$ & $n$ & $B$ \\
\hline GPPS & 9.4608 & 0.2583 & 0.0167 \\
POM & 2.1165 & 0.6853 & 0.0110 \\
PP & 2.8570 & 0.5081 & 0.0119 \\
\hline
\end{tabular}




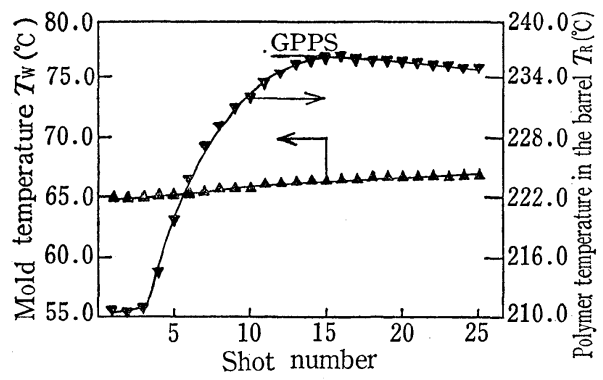

Fig. 6 Shot variations of mold temperature $T_{\mathrm{W}}$ and polymer temperature in the barrel $T_{R}$ when varying barrel temperature setting $\boldsymbol{T}_{\mathrm{RS}}$ largely (GPPS)

よび型内の樹脂温度の計測值 $T_{\mathrm{C}}{ }^{*}$ と, $T_{\mathrm{RS}}$ および $T_{\mathrm{ws}}$ を大さく変化させた時および成形立ち上がり時 に得られた $T_{\mathrm{W}}{ }^{\prime}$ と $T_{\mathrm{R}^{\prime}}$ とから，(11）式を用いて型 内の樹脂温度の変化量 $\Delta T_{\mathrm{C}}$ を計算した．計算は，粘 性発熱を考慮する場合としない場合とで行い，基準と なる粘性発熱による温度上昇 $\delta T_{\mathrm{g} \ominus \mathrm{n}}$ * は, 実測值と合 致する值として求めた．次に， $T_{\mathrm{C}}{ }^{\prime}=T_{\mathrm{C}}{ }^{*}+\Delta T_{\mathrm{C}}$ によ って $T_{\mathrm{W}^{\prime}}{ }^{\prime}, T_{\mathrm{R}}{ }^{\prime}$ の条件下に打利内型内樹脂温度 $T_{\mathrm{C}}{ }^{\prime}$ を計算した。

\section{4. 実験結果と考察}

4.1 加熱シリンダー温度設定值 $T_{\mathrm{RS}}$ を変化させた 場合

Table 1 に, 測定された粘度データから求めた（7） 式の定数を示す. 同表に示したBを（11）式中の $B$ と して用いた。

Fig. 6 に, GPPS に拉いて, 加熱シリンダー温度設 定值 $T_{\mathrm{RS}}$ を大きく変化させたときの，射出される樹 脂温度 $T_{\mathrm{R}}$ と金型温度 $T_{\mathrm{W}}$ のショット毎の変化を示 †.

Fig. 7 に, GPPS における各時刻の実測值と計算值 のショット毎の変化を示す. また, Fig. 8 に, PP に おける第 1 ショットおよび第 25 ショット目の型内の 樹脂温度波形の奏測值と計算值を示す.

Fig. 7 に示すよらに, 粘性発熱を考慮しない場合, 加熱シリンダー温度設定値 $T_{\mathrm{RS}}$ を低くした第 $1 \sim 3$ ショットまでは, 計算值が実測值よりも低くなり, 逆 に, $T_{\mathrm{RS}}$ を高くした第 4 第 25 ショットまでは, 計 算值が実測值よりも高くなった．次に，粘性発熱を考 慮した場合, 粘性発熱による温度上昇 $\delta T_{\text {gen }} *$ を $20^{\circ} \mathrm{C}$ と仮定することで，実測值と計算值とをほぼ合致させ ることが出来た． $T_{\mathrm{RS}}$ を変化させた場合, 実測值と計 算值との良好な一致を得ることのできる $\delta T_{\text {gen }}{ }^{*}$ は,

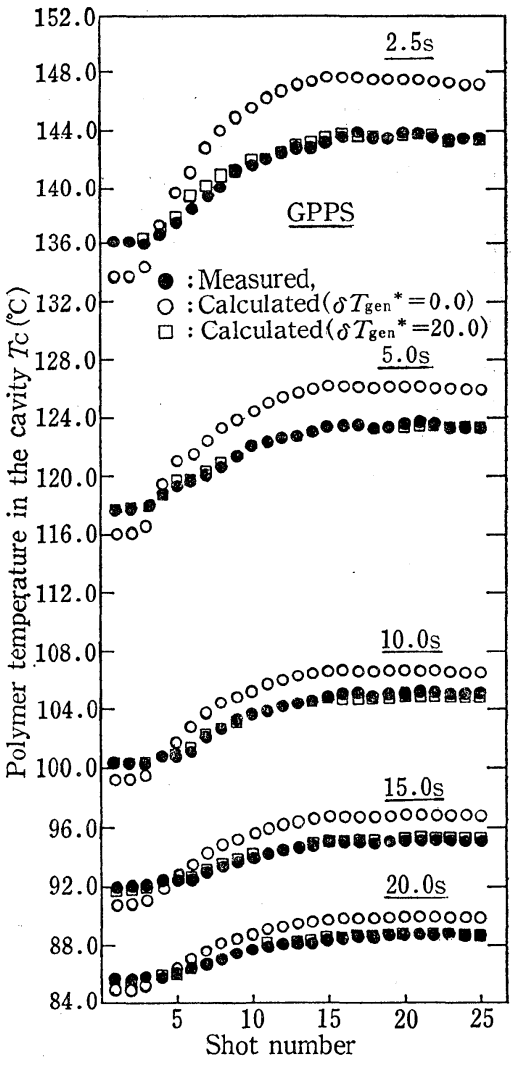

Fig. 7 Comparison of the variations of measured and calculated polymer temperature in the cavity in case of varying barrel temperature setting $T_{\mathrm{RS}}$ largely (GPPS)

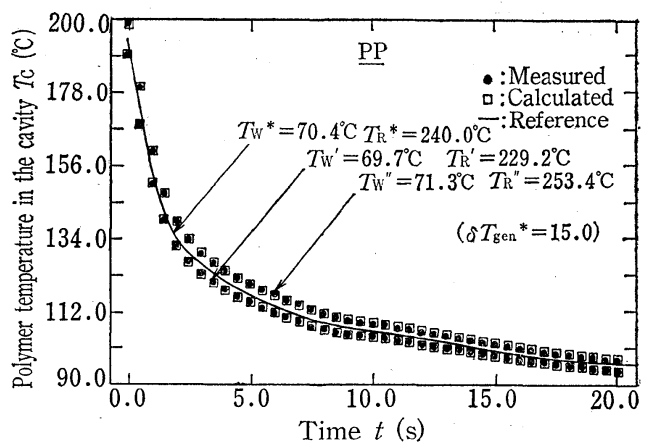

Fig. 8 Comparison of the variations of measured and calculated polymer temperature profiles in the cavity in case of varying barrel temperature setting $T_{\mathrm{RS}}$ largely $(P P)$

GPPS は $20^{\circ} \mathrm{C}, \mathrm{POM}$ は $20^{\circ} \mathrm{C}, \mathrm{PP}$ は $15^{\circ} \mathrm{C}$ となっ た.これらの值以下では， $\delta T_{\text {gen }}{ }^{*}$ が 0 の場合に比べ 


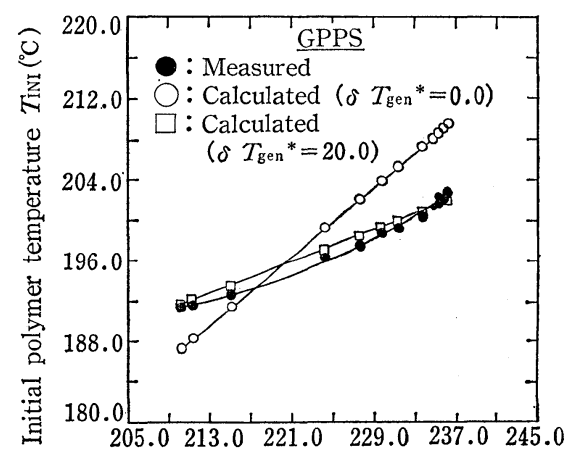

Polymer temperature in the baerel $T_{\mathrm{R}}\left({ }^{\circ} \mathrm{C}\right)$

Fig. 9 Relation between polymer temperature in the barrel $T_{R}$ and initial polymer temperature $\boldsymbol{T}_{\mathrm{INI}}$ when varying barrel temperature setting $T_{\mathrm{RS}}$ largely (GPPS)

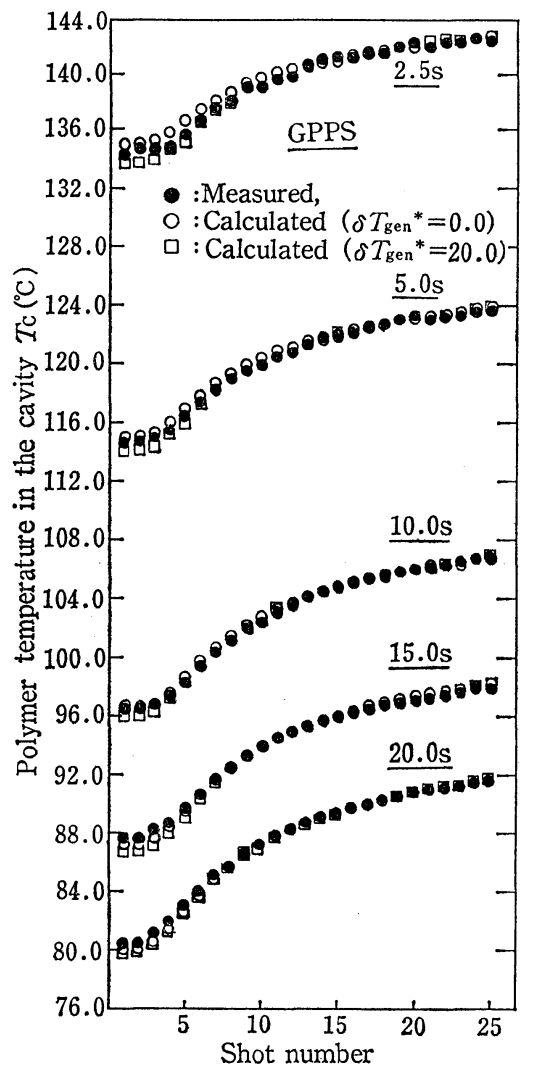

Fig. 11 Comparison of the variations of measured and calculated polymer temperature in the cavity in case of varying mold temperature setting $\boldsymbol{T}_{\mathrm{wS}}$ largely (GPPS)

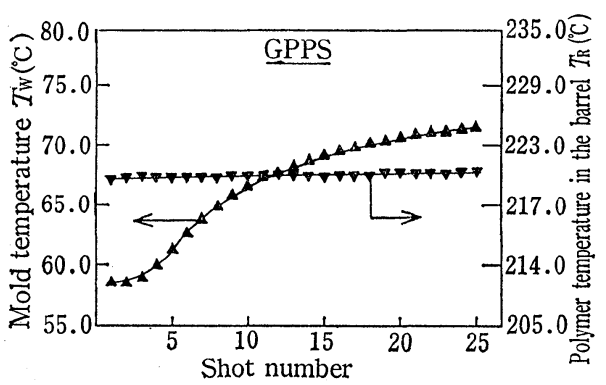

Fig. 10 Shot variations of mold temperature $T_{\mathrm{W}}$ and polymer temperature in the barrel $T_{R}$ when varying mold temperature setting $T_{\text {WS }}$ largely (GPPS)

\section{て，どの材料でも推定精度が向上した。}

$\delta T_{\text {gen }}$ * が 0 の場合, $T_{\mathrm{R}}$ の増加に起因する型内の 樹脂温度 $T_{\mathrm{C}}$ の増加が過大となった理由は (10) 式と （11）式とを比較すれば明らかなよらに， $\delta T_{\text {gen }}{ }^{*}=0$ の場合の $\left(\partial T_{\mathrm{C}} / \partial T_{\mathrm{R}}\right) T_{\mathrm{W}}$ が, $\delta T_{\mathrm{gen}}{ }^{*}>0$ の場合に比 べて大きいことにある. 射出される樹脂温度 $T_{\mathrm{R}}$ が增 加すると, 溶融粘度が減少し, 樹脂流動時の粘性発熱 量も減少する. このため, 実際に現れる型内の樹脂温 度増加量は, 粘性発熱を考虑しない計算值に比べて小 さくなる.

Fig. 9 飞, 型内の樹脂温度初期值 $T_{\mathrm{INI}}$ と, 射出さ れる樹脂温度 $T_{\mathrm{R}}$ との関係を示す. 粘性発熱を考慮し ない計算値は, 実測值に比べて勾配が大きくなってい るが, 粘性発熱を考慮した場合には, 計算值と実測值 の勾配を湾淕等しくすることができた。

以上の結果, 粘性発熱による温度上昇量 $\delta T_{\mathrm{gen}}{ }^{*}$ と, して適当な值を仮定し，(11）式を用いることによっ

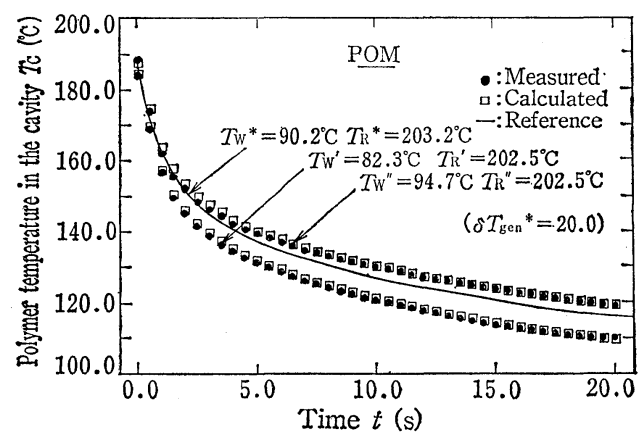

Fig. 12 Comparison of the variations of measured and calculated polymer temperature profiles in the cavity in case of varying mold temperature setting $\boldsymbol{T}_{\mathrm{WS}}$ largely(POM) 


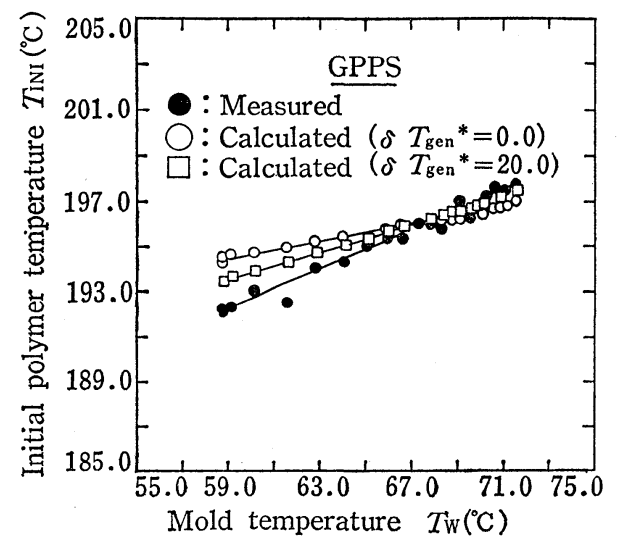

Fig. 13 Relation between polymer temperature in the barrel $T_{\mathrm{R}}$ and initial polymer temperature $\boldsymbol{T}_{\mathrm{INI}}$ when varying mold temperature setting $\boldsymbol{T}_{\mathrm{ws}}$ largely (GPPS)

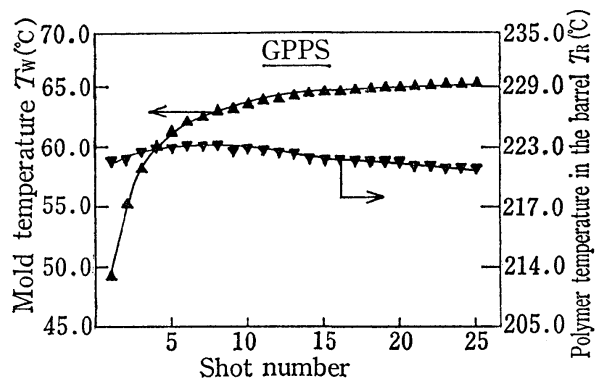

Fig. 14 Shot variations of mold temperature $T_{\mathrm{W}}$ and polymer temperature in the barrel $T_{\mathrm{R}}$ in case of the start up (GPPS : Constant mold temperature setting $T_{\mathrm{wS}}$ and barrel temperature setting $T_{\mathrm{RS}}$ )

て, 射出される樹脂温度 $T_{R}$ の変化に起因する型内の 樹脂温度変化を精度よく推定できることが確認された。

\section{2 金型温度設定値 $\boldsymbol{T}_{\mathrm{WS}}$ を変化させた場合}

Fig. 10 飞, GPPS 飞扮いて, 金型温度設定值 $T_{\mathrm{ws}}$ を大きく変化させたときの, 金型温度 $T_{\mathrm{W}}$ と射出され る樹脂温度 $T_{\mathrm{R}}$ のショット毎の変化を示す.

Fig. 11 に, GPPS 飞括ける各時刻の実測值と計算 值のショット毎の変化を示す. また, Fig. 12 に, POM に括ける第 1 ショット括よび第 25 ショットの型内の 樹脂温度波形の実測值と計算值を示す。

Fig. 10 と示すように，実測值と計算値とはよく一 致し, 最大の誴差は第 4 ショット目の $10(\mathrm{~s})$ 飞怙け る $2.6^{\circ} \mathrm{C}$ となった。 また（11）式を用いた計算にお

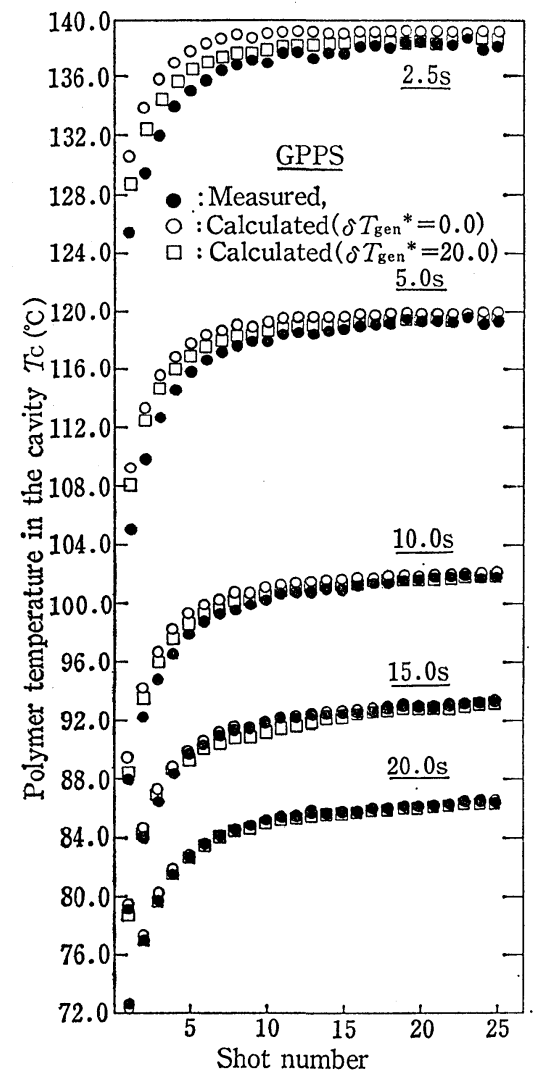

Fig. 15 Comparison of the variations of measured and calculated polymer temperature in the cavity in case of the start up (GPPS : Constant mold temperature setting $T_{\mathrm{Ws}}$ and barrel temperature setting $T_{\mathrm{RS}}$ )

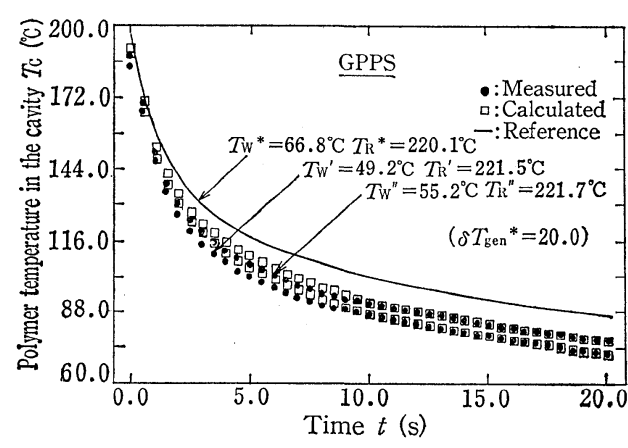

Fig. 16 Comparison of the variations of measured and calculated polymer temperature profiles in the cavity in case of the start up (GPPS : Constant mold temperature setting $T_{\mathrm{Ws}}$ and barrel temperature setting $T_{\mathrm{RS}}$ ) 
Table 2 Summary of the experimental results

\begin{tabular}{|c|c|c|c|c|c|c|c|}
\hline Condition & Material & $\begin{array}{l}\text { Mold temp. } \\
\text { set. } T_{\text {ws }}\left({ }^{\circ} \mathrm{C}\right)\end{array}$ & $\begin{array}{l}\text { Barrel temp. } \\
\text { set. } T_{\mathrm{RS}}\left({ }^{\circ} \mathrm{C}\right)\end{array}$ & $\begin{array}{l}\text { Mold temp. } \\
\text { meas. } T_{\mathrm{w}} \\
\left.\text { ( }{ }^{\circ} \mathrm{C}\right)\end{array}$ & $\begin{array}{l}\text { Melt temp. } \\
\text { meas. } T_{\mathrm{R}} \\
\left({ }^{\circ} \mathrm{C}\right)\end{array}$ & $\left|\begin{array}{l}\text { Initial polymer } \\
\text { temp. } T_{\text {INI }}\left({ }^{\circ} \mathrm{C}\right)\end{array}\right|$ & $\begin{array}{l}\text { Max. error* to } \\
\text { calculate } T_{\mathrm{C}}\left({ }^{\circ} \mathrm{C}\right)\end{array}$ \\
\hline \multirow{3}{*}{$\begin{array}{l}T_{\mathrm{RS}} \text { is } \\
\text { varied } \\
\text { largely }\end{array}$} & PSS & 50.0 & $210.0 \rightarrow 230.0$ & $65.4 \sim 67.2$ & $210.2 \sim 236.3$ & 191. 5 202. 6 & 1.5 \\
\hline & POM & 70.0 & $190.0 \rightarrow 210.0$ & $89.4 \sim 91.2$ & $193.0 \sim 219.0$ & $180.8 \sim 194.4$ & 2.7 \\
\hline & PP & 50.0 & $230.0 \rightarrow 250.0$ & $69.7 \sim 71.3$ & $229.2 \sim 254.9$ & $189.8 \sim 200.9$ & 1.4 \\
\hline \multirow{3}{*}{$\begin{array}{l}T \text { ws is } \\
\text { varied } \\
\text { largely }\end{array}$} & GPPS & $40.0 \rightarrow 60.0$ & 220.0 & $58.8 \sim 71.6$ & $219.7 \sim 220.6$ & $192.1 \sim 197.4$ & 1.3 \\
\hline & POM & $60.0 \rightarrow 80.0$ & 200.0 & $82.3 \sim 94.7$ & $202.3 \sim 203.0$ & 184. $2 \sim 188.4$ & 1.7 \\
\hline & PP & $40.0 \rightarrow 60.0$ & 240.0 & $63.1 \sim 75.4$ & $239.7 \sim 240.6$ & 188. $8 \sim 195.2$ & 1. 4 \\
\hline \multirow{3}{*}{$\begin{array}{l}\text { Start up } \\
\left(T_{\mathrm{w}} \text { is }\right. \\
\text { unstable) }\end{array}$} & GPPS & 50.0 & 220.0 & $49.2 \sim 65.3$ & 221. $4 \sim 223.1$ & $184.8 \sim 195.5$ & 1.6 \\
\hline & POM & 7 & 200.0 & $66.1 \sim 89.0$ & $189.8 \sim 200.9$ & $165.3 \sim 185.8$ & 2.4 \\
\hline & $\mathrm{PP}$ & 50.0 & 240.0 & $48.8 \sim 68.8$ & $236.4 \sim 245.2$ & 169. $4 \sim 197.8$ & 4.7 \\
\hline \multirow{3}{*}{$\begin{array}{l}\text { Stadard** } \\
\text { condition }\end{array}$} & GPPS & 50.0 & 220.0 & $66.7 \sim 66.8$ & $220.1 \sim 221.7$ & $195.9 \sim 196.5$ & Reference value \\
\hline & POM & 70.0 & 200.0 & $90.2 \sim 90.4$ & $202.5 \sim 203.2$ & $187.1 \sim 188.2$ & Reference value \\
\hline & PP & 50.0 & 240.0 & $70.4 \sim 70.5$ & $239.9 \sim 240.6$ & 193. $8 \sim 195.0$ & Reference value \\
\hline
\end{tabular}

* Maximum error in 25 shots. Error is averaged for $20 \mathrm{~s}$. from the start of mold filling.

** $T_{\mathrm{W}}$ and $T_{\mathrm{R}}$ in this condition was used as the reference value $T_{\mathrm{W}}{ }^{*}$ and $T_{\mathrm{R}}{ }^{*}$ to calculate $T_{\mathrm{C}}{ }^{*}$.

いて, 粘性発熱による温度上昇量 $\delta T_{\text {gen }} *$ が $0^{\circ} \mathrm{C}$ の 時と $20^{\circ} \mathrm{C}$ の時とで, 実測值と計算値との差異に大 差は無かった. しかし型内の樹脂温度初期値 $T_{\text {INI }}$ の 推定精度は, 粘性発熱を考虑することによって改善さ れた. Fig. 13 飞型内の樹脂温度初期値 $T_{\mathrm{INI}}$ と, 金 型温度 $T_{\mathrm{w}}$ との関係を示す. $\delta T_{\mathrm{gen}}{ }^{*}=20^{\circ} \mathrm{C}$ の場合, $\delta T_{\mathrm{gen}}{ }^{*}=0^{\circ} \mathrm{C}$ の場合に比べて， $T_{\mathrm{W}}$ と $T_{\mathrm{INI}}$ との勾配 が大きくなった。この理由は（10）式と（11）式に示 されるように, $\delta T_{\mathrm{gen}}{ }^{*}=20^{\circ} \mathrm{C}$ の $\left(\partial T_{\mathrm{C}} / \partial T_{\mathrm{W}}\right)_{T_{\mathrm{R}}}$ が, $\delta T_{\mathrm{gen}}=0^{\circ} \mathrm{C}$ の場合よりも大きいことにある.

以上の結果，金型温度 $T_{\mathrm{w}}$ が大きく変化した場合 にも，（11）式によって，型内の樹脂温度変化を精度 よく推定できることが確認された。

\section{3 成形立ち上がり時の型内の樹脂温度变化}

Fig. 14 亿，GPPS に打いて，成形立ち上がりに程 ける金型温度 $T_{\mathrm{W}}$ と射出される樹脂温度 $T_{\mathrm{R}}$ のショ ット毎の変化を示す． $T_{\mathrm{W}}$ は急激な上昇を示したが， $T_{R}$ は洼とえど変化していない．

Fig. 15 に, GPPS 飞拈许る各時刻の実測值と計算 值のショット毎の変化を示す．また，Fig. 16 には， GPPS そ括ける第 1 拈よび第 2 ショットの型内の樹脂 温度波形の実測值と計算値を示す。

金型に樹脂が充填されてから，時間を経過するに従 って, 実測値と計算值との差異は漸減している. 実測 值と計算值との最大の差異は，粘性発熱を考慮した場 合，成形第 1 ショット目に拁ける時刻 $2.5(\mathrm{~s})$ の $4.0^{\circ} \mathrm{C}$ である. 乙かし，同じ第 1 ショット目に执いて も, 時刻が $5.0(\mathrm{~s})$ では, その差異は $3.0^{\circ} \mathrm{C}$ となり, $10.0(\mathrm{~s})$ では $0.5^{\circ} \mathrm{C}, 15.0(\mathrm{~s})$ では $0.3^{\circ} \mathrm{C}, 20.0$ （s）では $0.3^{\circ} \mathrm{C}$ へと減少している，このように，時 間を経過するに従って, 実測值と計算值との差異が減 少する傾向は，他の材料についても同様であった．ど の成形ショットでも, 特に充填後の初期には, 実測值 は計算值に比べて低い值を示した。 この原因の一つに は, 射出された樹脂からの伝熱によって, 金型壁面温 度が実際には变化するにもかかわらず, 本報の予測式 では，金型壁面温度を常に一定と仮定したことが考え られる．溶融樹脂が金型に射出されると，樹脂から金 型壁面に伝わる熱量によって，金型壁面温度は上昇を 示す．壁面温度の上昇は，特に，射出された樹脂と壁 面との温度差の大きい充填直後に顕著となる．金型壁 面の温度上昇は，金型と樹脂それぞれの比熱や接触形 態，および金型内部の温度勾配などに影響される．金 型内部の温度勾配は，成形立ち上がり時と，金型温度 $T_{\mathrm{W}}$ が安定した条件下とでは異なることが予測される。 したがって，成形立ち上がり時に括ける実測值と計算 值との差異を減少させるためには，金型と樹脂との熱 交換作用により，金型壁面温度が上昇することや，金 型内部の温度勾配を考慮することが必要である。

Table 2 に, 各成形条件下に括忊る金型温度 $T_{\mathrm{W}}$ 拧 よび射出される樹脂温度 $T_{\mathrm{R}}$ の変化量, ならびに実測 值と計算值との 20 秒間の平均誤差を示す. 成形立ち 上がり時に PP で誤差が $4.7^{\circ} \mathrm{C}$ となることを除き， 概略の誤差は $1.3 \sim 2.7^{\circ} \mathrm{C}$ となった。

以上の結果，（11）式により，どのような温度変化 の条件下でも，ほぼ充分な精度で型内の樹脂温度変化 を推定できることが確認された。 


\section{4 成形品重量予測への適用性}

Fig. 17 に, GPPS に打ける型内の 樹脂温度計算値 $T_{\mathrm{C}}$ と, 型内圧力実測值 $p_{\mathrm{C}}$, および成形品重量 $W_{\mathrm{C}}$ との関連を示す。ただし，計算には（13）式を用い, 基準となる成形ショットにおいて, 型内の樹脂温度が その流動停止温度 $T_{\mathrm{nf}}$ である $130^{\circ} \mathrm{C}$ を迎兄る固定さ れた時刻を対象とした．この場合 $T_{\mathrm{C}}, p_{\mathrm{C}}$ と $W_{\mathrm{O}}$ との 間には，図に示すような明瞭な関係が得られた。そし て,これら実験值の間の関連を Spencer \& Gilmore

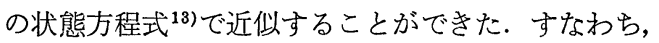
(11）式を用いることによって， $T_{\mathrm{C}} ， p_{\mathrm{C}}$ と $W_{\mathrm{C}}$ との 明瞭な相関性を得ることができた.（11）式による $T_{\mathrm{C}}$ の計算には，射出開始前の金型温度 $T_{\mathrm{W}}$ 忬よび射出さ れる樹脂温度 $T_{\mathrm{R}}$ の計測值を用いている.このため, 保圧冷却段階で決定される成形品重量変化をあらかじ め金型に樹脂を充填する前に予湘することができる.

以上の結果，（11）式を用いれば，型内の樹脂温度, 樹脂圧力之成形品重量との間に明確な相関性を確認で きるので，(11）式は，保圧冷却段階で決定される成 形品重量をあらかじめ金型に樹脂を充媜する前化予測 して制御する際の有効な手法となることが確認された。

\section{5. 結 言}

本報では, 温度変化を考慮したプロセス制御におい てその重要なステップとなる型内の樹脂温度変化の予 測方法を検討した。（11）式は，主に 熱伝導方程式の 線形性に基づいて解析的に得られた式であり, 型内の 樹脂温度変化が依存する樹脂物性值特よび計算の前提 条件を示している。 また，予測の対象となる任意時刻 の型内の樹脂温度変化と, 充填前に計測可能な金型お よび射出される樹脂の温度変化との関係を示している。

本予測式の推定精度を実験的に確認した結果, 実際 の成形時に発生する型内の樹脂温度変化を良好な精度 で推定できることが確認されたままた，本式を用いれ ば, 保圧冷却段階に拈いて決定される成形品重量变化 を，充填前に予測することが可能となった。

以上の結果から, 本報の予測式は, 精度, 信頼性, 扣よび取り扱い易さの諸点に扣いて, 温度变化に起因 する成形品品質の変動を解消し, かつ型内の樹脂の状 態変化をあらかでめ金型に樹脂を充填する前に予測し て制御する適応制御に和いて，その有効な手法となる ものと期待される.

\section{参考文献}

1）焼本数利, 前川善一郎, 濱田泰以, 酒井忠基 : 成 形加工, 3(8), 567 (1991)

2）焼本数利, 前川善一郎, 濱田泰以, 酒井忠基 : 成

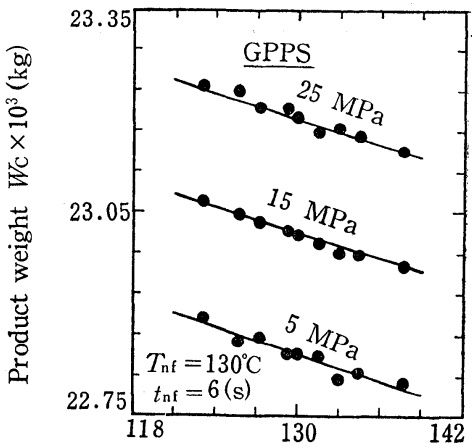

Calculated temperature $T_{\mathrm{C}}\left({ }^{\circ} \mathrm{C}\right)$

Fig. 17 Relation of product weight $W_{\mathrm{C}}$, cavity pressure $p_{\mathrm{C}}$ and calculated polymer temperature $T_{\mathrm{C}}$ when varying mold temperature $T_{\mathrm{W}}$, polymer temperature in the barrel $T_{R}$, and holding pressure $p_{\mathrm{L}}$ (GPPS)

(๑): Measured, - : Approximated by the state equation of SPENCER \& GILMORE)

形加工, 3(10), 679 (1991)

3) Menges, G., Hellmeyer, H. O., Vargel, J.: PV, 25(5), 275 (1974)

4) Menges, G.: $P V, 25(5), 265$ (1974)

5) Nunn, R. E.: Plastics Engineering, 45 (1989).

6) Michaeli, W., Lauterbach, M.: Kunststoffe, 79(9), 852 (1989)

7）伊藤公正：プラスチック成形加工：加熱と冷却, 第 3 章, 69 (1971), 工業調査会

8）焼本数利, 前川善一郎, 濱田泰以, 酒井忠基, 白 銀屋司：成形加工，91，91（1991）

9) Ahmadian, M. T., Burmeister, L. C.: Polym. Eng. Sci., 30(13), 776 (1990)

10) Winter, H. H.: "Viscous Dissipation in Shear Flows of Molten Polymers", Advances in Heat Transfer, Hartnett and Irvine, eds., 13, 205-266 (1977)

11) Forrest, G., Wilkinson, W. L.: Trans. Instn. Chem. Engrs., 51, 331(1973)

I2）電通国際情報サービス：MOLDFLOW SYSTEM MANUAL (1980)

13) Spencer, R. S., Gilmore, G. D.: J. of Applied Physics, 20, 502(1949)

\section{付 録}

\section{A.1（2）式の証明}

(1) 式の解析解は次式で与兄られる7).

$$
\begin{aligned}
& T_{\mathrm{C}}(t, x)=\left(T_{\mathrm{W}}-D / 2\right)+\left(A_{1}+A_{2} \cdot x\right) \cdot D \\
& \quad+\left(T_{\mathrm{R}}-T_{\mathrm{W}}\right) \cdot \sum_{j=0}^{\infty} \exp \left(-\alpha \cdot n_{j}{ }^{2} \cdot t\right) \cdot C_{j}
\end{aligned}
$$




$$
\cdot\left[\frac{\lambda}{h} \cdot n_{j} \cdot \cos \left(n_{j} \cdot x\right)+\sin \left(n_{j} \cdot x\right)\right]
$$

ただし，

$$
\begin{aligned}
& A_{1}=\left(1-\frac{M}{h}\right), \quad A_{2}=-\left(\frac{M}{\lambda}\right), \\
& \frac{1}{\lambda}=\frac{2}{M}+\frac{S}{h}, \quad \alpha=\frac{\lambda}{\rho \cdot c_{p}}, \\
& \tan \left(n_{j} \cdot \frac{S}{2}\right)=\frac{h}{\lambda \cdot n_{j}}, \\
& C_{j}=\frac{4 \cdot(h / \lambda)^{2}}{n_{j} \cdot\left\{\left[n_{j}{ }^{2}+(h / \lambda)^{2}\right] \cdot S+2 \cdot(h / \lambda)\right\}}
\end{aligned}
$$

（14）式を $T_{\mathrm{W}}, D$ ，および $T_{\mathrm{R}}$ について偏微分すれば 次式を得る。

$$
\begin{aligned}
& \left(\frac{\partial T_{\mathrm{C}}}{\partial T_{\mathrm{W}}}\right)_{T_{\mathrm{R}}, D}=\frac{T_{\mathrm{R}}-T_{\mathrm{C}}+E \cdot D}{T_{\mathrm{R}}-T_{\mathrm{W}}} \\
& \left(\frac{\partial T_{\mathrm{C}}}{\partial D}\right)_{T_{\mathrm{W}}, T_{\mathrm{R}}}=E \\
& \left(\frac{\partial T_{\mathrm{C}}}{\partial T_{\mathrm{R}}}\right)_{T_{\mathrm{W}}, D}=\frac{T_{\mathrm{C}}-E \cdot D-T_{\mathrm{W}}}{T_{\mathrm{R}}-T_{\mathrm{W}}}
\end{aligned}
$$

（1）式で示した熱伝導方程式は線形であるが，こ の線形性は次式で表される.

$$
\begin{aligned}
\Delta T_{\mathrm{C}}= & \left(\frac{\partial T_{\mathrm{C}}}{\partial T_{\mathrm{W}}}\right)_{D, T_{\mathrm{R}}} \cdot \Delta T_{\mathrm{W}}+\left(\frac{\partial T_{\mathrm{C}}}{\partial D}\right)_{T_{\mathrm{W}}, T_{\mathrm{R}}} \cdot \Delta D \\
& +\left(\frac{\partial T_{\mathrm{C}}}{\partial T_{\mathrm{R}}}\right)_{T_{\mathrm{W}}, D} \cdot \Delta T_{R}
\end{aligned}
$$

本式に偏微分項を代入すれば，ただちに（2）式を得 る.

\section{A.2 熱伝達率 $\boldsymbol{h}$ の影響}

通常， h山無限大として扱われることが多いが，こ の場合には（3）式のEは次の上うになる.

$$
E=1 / 2-x / S
$$

すなわち, 本式と（2）式から明らかなように, $h=\infty$ の時には, $\Delta T_{\mathrm{C}}$ は樹脂物性值入にも依存しない。

\section{A.3 (4) 式の適用範囲}

（2）式から（4）式を導くのは容易である.（4） 式は, 無限平板のみならず, 壁面温度が均一な二次元 平板, 三次元值方体, 円柱, 球, 半無限固体, おょび 円環でも成立する.このため，（2）式に拈いて $\Delta T_{\mathrm{C}}$ が $h$ と $\lambda$ に依存する原因は $T_{\mathrm{W} 1}$ と $T_{\mathrm{W} 2}$ とが異な ることである.

\section{A.4（9）式の証明}

（7）式で示される, べき乗法則に従う流体に括い $\tau$, 粘性発熱を考慮しない場合 $\left(\eta \cdot \dot{\gamma}^{2}=0\right)$ の (6) 式の解 $T_{\mathrm{L} 0}$ は次式で与兄られる9).

$$
\frac{T_{\mathrm{L} 0}-T_{\mathrm{W}}}{T_{\mathrm{R}}-T_{\mathrm{W}}}=\sum_{j=0}^{\infty} C_{1 j} \cdot R_{j}(\zeta) \cdot \exp \left(-\frac{n+1}{n+3} \cdot \lambda_{j}^{2} \cdot z^{*}\right)
$$

$$
\begin{aligned}
& C_{1 j}=\frac{\int_{0}^{1}\left(1-\zeta^{n+1}\right) \cdot \zeta \cdot R_{j}(\zeta) \mathrm{d} \zeta}{\int_{0}^{1}\left(1-\zeta^{n+1}\right) \cdot \zeta \cdot R_{j}(\zeta)^{2} \mathrm{~d} \zeta} \\
& z^{*}=\frac{\alpha \cdot \pi}{Q} \cdot z, \quad \zeta=\frac{r}{R}, \quad R_{j}(\zeta): \zeta \text { の関数 }
\end{aligned}
$$

粘性発熱を考慮した場合，（6）式の解 $T_{\mathrm{L}}$ は次式 で与えられる。

$$
\begin{aligned}
\frac{T_{\mathrm{L}}-}{T_{\mathrm{R}}-T_{\mathrm{W}}} & =\sum_{j=0}^{\infty} C_{1 j} \cdot R_{j}(\zeta) \cdot \exp \left(-\frac{n+1}{n+3} \cdot \lambda_{j}{ }^{2} \cdot z^{*}\right) \\
& +\frac{\delta T_{\text {gen }}}{T_{\mathrm{R}}-T_{\mathrm{W}}} \\
\delta T_{\text {gen }} & =\frac{m \cdot \exp \left[-B \cdot\left(T_{\mathrm{R}}+273\right)\right] \cdot R^{2}}{\lambda \cdot\left(n^{2}+n+2\right)^{2}} \cdot\left[-\frac{Q}{\pi \cdot R^{3}}\right. \\
& \times(n+3)]^{n+1} \cdot\left[\left(1-\zeta^{n^{2}+n+2}\right)-\sum_{j=0}^{\infty} C_{2 j} \cdot R_{j}(\zeta)\right. \\
& \left.\times \exp \left(-\frac{n+1}{n+3} \cdot \lambda_{j}{ }^{2} \cdot z^{*}\right)\right]
\end{aligned}
$$

ここで,

$$
C_{2 j}=\frac{\int_{0}^{1}\left(1-\zeta^{n+1}\right) \cdot\left(1-\zeta^{n^{2}+n+2}\right) \cdot \zeta \cdot R_{j}(\zeta) \mathrm{d} \zeta}{\int_{0}^{1}\left(1-\zeta^{n+1}\right) \cdot \zeta \cdot R_{j}(\zeta)^{2} \mathrm{~d} \zeta}
$$

すなわら（16）式と（17）式とを組み合わせると， （17）式は次のように表される.

$$
\frac{T_{\mathrm{L}}-T_{\mathrm{W}}}{T_{\mathrm{R}}-T_{\mathrm{W}}}=\frac{T_{\mathrm{L} 0}-T_{\mathrm{W}}}{T_{\mathrm{R}}-T_{\mathrm{W}}}+\frac{\delta T_{\mathrm{gen}}}{T_{\mathrm{R}}-T_{\mathrm{W}}}
$$

したがって， $T_{\mathrm{L}}=T_{\mathrm{L} 0}+\delta T_{\text {gen }}$ となる。

\section{A.5（10）式の証明}

\section{(9) 式より,}

$$
\left(\frac{\partial T_{\mathrm{L}}}{\partial T_{\mathrm{W}}}\right)_{T_{\mathrm{R}}}=\left(\frac{\partial T_{\mathrm{L} 0}}{\partial T_{\mathrm{W}}}\right)_{T_{\mathrm{R}}}+\left(\frac{\partial \delta T_{\mathrm{gen}}}{\partial T_{\mathrm{W}}}\right)_{T_{\mathrm{R}}}
$$

また，（9）式，(16）式, および（18）式より,

$$
\begin{aligned}
& \left(\frac{\partial T_{\mathrm{L} 0}}{\partial T_{\mathrm{W}}}\right)_{T_{\mathrm{R}}}=\frac{T_{\mathrm{R}}-T_{\mathrm{L} 0}}{T_{\mathrm{R}}-T_{\mathrm{W}}}=\frac{T_{\mathrm{R}}-T_{\mathrm{L}}}{T_{\mathrm{R}}-T_{\mathrm{W}}}+\frac{\delta T_{\mathrm{gen}}}{T_{\mathrm{R}}-T_{\mathrm{w}}} \\
& \left(\frac{\partial \delta T_{\mathrm{gen}}}{\partial T_{\mathrm{W}}}\right)_{T_{\mathrm{R}}}=0
\end{aligned}
$$

以上により, 次式を得る.

同様に,

$$
\left(\frac{\partial T_{\mathrm{L}}}{\partial T_{\mathrm{W}}}\right)_{T_{\mathrm{R}}}=\frac{T_{\mathrm{R}}-T_{\mathrm{L}}}{T_{\mathrm{R}}-T_{\mathrm{W}}}+\frac{\delta T_{\mathrm{gen}}}{T_{\mathrm{R}}-T_{\mathrm{W}}}
$$

$$
\left(\frac{\partial T_{\mathrm{L}}}{\partial T_{\mathrm{R}}}\right)_{T_{\mathrm{W}}}=\left(\frac{\partial T_{\mathrm{L} 0}}{\partial T_{\mathrm{R}}}\right)_{T_{\mathrm{W}}}+\left(\frac{\partial \delta T_{\mathrm{gen}}}{\partial T_{\mathrm{R}}}\right)_{T_{\mathrm{W}}}
$$

(9) 式，(16）式, 牤よび（18）式より,

$$
\begin{aligned}
& \left(\frac{\partial T_{\mathrm{L} 0}}{\partial T_{\mathrm{R}}}\right)_{T_{\mathrm{W}}}=\frac{T_{\mathrm{L} 0}-T_{\mathrm{W}}}{T_{\mathrm{R}}-T_{\mathrm{W}}}=\frac{T_{\mathrm{L}}-T_{\mathrm{W}}}{T_{\mathrm{R}}-T_{\mathrm{W}}}-\frac{\delta T_{\mathrm{gen}}}{T_{\mathrm{R}}-T_{\mathrm{W}}} \\
& \left(\frac{\partial \delta T_{\text {gen }}}{\partial T_{\mathrm{R}}}\right)_{T_{\mathrm{W}}}=-B \cdot \delta T_{\text {gen }}
\end{aligned}
$$

以上により, 次式を得る.

$$
\left(\frac{\partial T_{\mathrm{L}}}{\partial T_{\mathrm{R}}}\right)_{T_{\mathrm{W}}}=\frac{T_{\mathrm{L}}-T_{\mathrm{W}}}{T_{\mathrm{R}}-T_{\mathrm{W}}}-\left(\frac{1}{T_{\mathrm{R}}-T_{\mathrm{W}}}+B\right) \cdot \delta T_{\text {gen }}
$$

上記の各式で, $T_{\mathrm{INI}}=T_{\mathrm{L}}$ とすれば（10）式を得る. 